\title{
COMPARATIVE STUDIES ON ATTENUATED AND INACTIVATED OIL EMULSION EGG DROP SYNDROME (EDS) VIRUS VACCINE PREPARED ON CAICKEN LIVER CELL CULTURE AND DUCR EGGS VACCINE
}

\author{
Nancy Botros Rofall \\ Veterinary Serum and Vacclne Research \\ Inststule-Abbasla-Calso, Egypt
}

\begin{abstract}
The EDS.76 vacxthes produced elther in the allantoic cavlly of embryonaled duck eggs or in chicken liver cell cullures were comparalwely sludied as a living atlenualed and inaodvated oll emulsion vaccines, Lue allenualed vaccine was prepared by propagation of EDS-76 utrus in duck eggs followed by 30 passages on prepared chicken liver ,ICLd cells. The onset of CPE and best lime of vinus harvesing was delermined for each virus passages on CL cells. 25th passages on CL cells, EDS virus loss its palhogeniclty and gave $100 \%$ protection to the vaccinated chicks. Inaclivaled uinus was prepared in ellher duck eggs or CL cells. Live attenuated and inactivated oll emulsion CL cell adapted EDS vacines gave high immunity to the suscepuble chicks based on lymphocyle blastogenesls assay, serum meutralization test, HI and challenge test as well as the inactivated duck eggs oll emulsion vaccine. The CL cells prepared vaccine gave $100 \%$ protection 10 the susceptible chicken when kept at $4^{\circ} \mathrm{C}$ for 4 months.
\end{abstract}

\section{INTRODUCTION}

The egg drop syndrome (EDS) virus was isolated for the first time in 1976 by Van Eck ot $a$. at the Buxton Conference on Avlan Adenoviruses and Infectlous Bronchitis and termed "egg drop syndrome".

In Egypt EDS virus isolated for the first tume from duck farms (Hemoude, 1988) and from chicken farms by Ahmod (1906).

EDS disease affects laying hens cause a sudden and frequently drop in egg production with laying of soft shelled eggs (Holmes ot al., 1989) which perslgt for 4-10 weeks (Ahmed, 199B).

Zank et al. (1882) mentioned that in chicken liver cells, peak virus and intracellular HA titers 
were rcached after 48 hours and peak extracellular HA titers were seen after 72 hours.

Plischke (1989) reported that embryonated chicken ilver cell culture has proved to be an appropriate and sensitive substrale for propagation of virus of infectlous laryngotracheltis (ILT). infectious bronchlus (IB). infectious bursal Disease (IBD) and egg drop syndrome virus of fowl.

Bragg et al. (1891) found that a cytopathlc agent was subsequently isolated in chicken embryo liver cell cultures and identified as EDS virus by haemagglutination Inhibition and neutrallzation test.

Swaln et al. (1993) found that EDS-76 virus repllcated best to the highest lite in chicken embryo liver cells and less In duck embryo liver cells and duck embryo fibroblast cells. The rytopathic effect in chicken liver cells was marked by the presence of round and refractle cells and detachment of cells from the glass surface.

Kaur et al. (1997) stated that Immune response to líve and Inactlvated EDS virus can be detected by neutralizing antibody response and challenge reaction.

The ain of this present work is the comparison of the immune response of the prepared llvIng attenualed and inactivated vaccine elther $\mathrm{CL}$ cells propagated in $\mathrm{Cl}$ cells or in duck eggs vac. cine.

\section{MATERIAL AND METHODS}

\section{1-Chicks:}

Susceptible 21 -days old Hubbard chicks ivere used for vaccine evaluation.

\section{2-Vlrus straln:}

EDS-76 virus strain supplied by the Central Veterinary Labosatory, Weybridge. England.

\section{3-Embryos:}

* One day old SPF chicks were used for preparation of chicken liver cell cultures supplied by Pfirschke (1980).

- Embryonated duck eggs. They were obtalned from United Company for Poultry Production and used for propagation and titration of EDS. 76 virus.

4-Cell cultures medla, rcagents and solution:

\subsection{Minimum Essential Medium (MEM):}

It was used as growth medium with $10 \%$ newborn calf serum and malntenance medium with $2-3 \%$ newborn calf serum in pH 7.2. It was supplied by Sigma. 


\subsection{Preparation of Lactivated vacclae:}

EDS virus was inactivated with $0.1 \%$ formalin and emulsifned with paraffin oll. The prepared vaccines were tested for sterllity. potency and challenge according to Lee-Amt and Hopktns (1982).

\section{Methods:}

\subsection{Virus titration:}

It was carried out according to Pedro and Graham (1980). The virus titre was calculated according to Reed and Muench (1938).

\subsection{Serum neutralization test:}

According to the method described by Rossiter et al. (1985).

\subsection{Haemagglutination inhibltion test (Ka);}

It "as carrted out according to Anon (1971).

\subsection{Lymphocyte blastogenests assay:}

It ras applied according to Lee (1984).

\section{RESULTS \& DISCUSSION}

EDS-76 is an Infectlous viral disease of paramount economlc importance to the farmers (Van Eck ct al., 1976) characterized by drop in egg production quantlty and quality (McFerran et a1., 1978).

Kulled vaccines as well as live vaccines are being used for the prevention of clinical disease in birds (Kaur et al., 1987).

Fiumoral antbody response has been demonstrated to EDS-76 Infection and vaccination. Recently cell mediated immunity response has also been demonstrated following EDS-76 virus In. oculation (Kumar ot al., 1989).

Embryonic chicken liver cell culture has proved to be an appropiate and sensitive substrate for propagation of egg drop syndrome virus (PAsachke, 1989).

Table (1) shows the infectivity titre of the 3 passages of original propagated and titrated in embryonated duck eggs that reached to $10^{6} \mathrm{E}^{\mathrm{C}} \mathrm{D}_{50} / \mathrm{ml}$.

Dealing with results in table (2) propagation of the original EDS virus for 30 serial passages on chicken liver cell cultures and observing the start of CPE (round and refractile cells and de- 


\section{Nancy Botros Rofall}

tachment of these cell from the glass surface) and the best time of harvesting indicated that the virus titre increase to the beak and reached to $10^{12} \mathrm{TCID}_{50} / 0.1 \mathrm{ml}$ after 10 passages.

This result agree with those obtained by Swain et al. (1993) who found that the EDS-76 virus replicated best in primary chicken embryo liver cells and CPE can be observed by 24-48 lours after virus inoculation, and agree also whth Calock et al. (1997) who found that the virus was rapidly adapted to chicken liver cell cultures producing optimum titre of $10^{7} \mathrm{TCID}_{50} / \mathrm{ml}$ at $7^{\text {th }}$ passage within $5^{\text {th }}$ day post inoculation.

Tables ( 3 and 4) shows that passage $25^{\text {th }}$ was completely safe and protectlve to chickens 21 day old vaccinated by $1.0 \mathrm{ml} / \mathrm{M}$ of attenuated virus that ubserved for $2 \mathrm{I}$ days post inoculation and then challenged by virulent EDS. 76 virus and kept under observation for 15 days after challenge.

From this results the $24^{\text {th }}$ passage of EDS virus on chicken liver cell gave a completc attenuated live protective virus that could be use for preparation of attenuated and formalln Inactivated oll emulsion EDS vaccines which used In this study in comparison with the inaclivated embryonated duck egg propagated EOS virus vaccine.

The final and main objeclive of this study was to prepare potent live altenuated and inactivated EDS-76 vaccines on CL cells and evaluate thelr effcacy in susceptible chickens in comparison with the local embryonated duck eggs prepared vaccine. The prepared vaccines were sterlle as clear in table (5).

The encacy of the different prepared vaccines was tested to determine the level and duration of cell mediated immune response for each of the investigated vaccines as mentioned in table (6). Antubodles were monitored in sera collected from vaccinated and non vaccinated birds by $\mathrm{HIl}$ and SNT tIll 12 weeks post vaccinatlon. the Immune response was measurcd in table (7).

Tables (7.8) show the peak of SNT and $\mathrm{HI}$ value from the $4^{\text {th }} 1.012^{\text {th }}$ weeks post vaccination with live attenuated and from 4 to 12 weeks with inactivated $C L$ cell vaccines whlle it was 6 to 12 weeks in duck eggs inactivated vaccine. That is agree with Khalaf (1981) who found that the neutralting and baemagglutination inhtbition antibodses in blood serum of vacclnated chlcks glve peak tltres in between 7 and 12 weeks post vacclnation. This result has been reported by Phillps (1973) and Adu et al. (1989).

Table (9) Indicated that after challenge test the three prepared vaccines ilive attenuated. inactlvated $\mathrm{CL}$ cell cultures vaccines and the embryonated duck eggs inactivated vaccine) gave 100\% protection for three serlal months post challenge with virulent EDS-76 virus.

The keeping quality of the prepared vaccine was tested for 4 months in $-20^{\circ} \mathrm{C}$ and $4^{\circ} \mathrm{C}$ for live 
attenuated and both inactivated vaccine respectively as shown in table (10) which clear that they gave $100 \%$ protection percent. As mentioned by Rhee et al. (1987) the vaccine afforded Immun(ty as long as six months. From the prevlous results we could conclude that the successful trlals of propagation and attenuation of EDS.76 virus In CL cell culture, It is rapid. specific. sensilive and reduce the probabllity of contamination as in the EDS-76 virus harvested from commerclal duck eggs that collected from different sources that can carry different contaminants as bactena. fungus and mycoplasina. 
Table (1) Infectivity titre of EDS-76 virus propagated in embryonated duck eggs

\begin{tabular}{|c|c|}
\hline No. of passages & $\log _{10}$ EID $_{50} / \mathrm{ml}$ \\
\hline 1 & 5 \\
\hline & 5 \\
\hline
\end{tabular}

Table (2) Propagation and titration of EDS-76 virus propagated on chicken liver cell cultures (CL)

\begin{tabular}{|c|c|c|c|}
\hline $\begin{array}{c}\text { No. of } \\
\text { passages }\end{array}$ & $\begin{array}{c}\text { time of CPE } \\
\text { appeared post } \\
\text { inoculation } \\
\text { (hours) }\end{array}$ & $\begin{array}{c}\text { time of } \\
\text { harvestation post } \\
\text { inoculation } \\
\text { (days) }\end{array}$ & $\begin{array}{c}\log _{10} \\
\text { ICID }_{50} / \mathrm{mI}\end{array}$ \\
\hline 1 & 72 & 5 & 3 \\
\hline 5 & 48 & 4 & 7 \\
\hline 15 & 24 & 2 & 12 \\
\hline 20 & 24 & 2 & 11 \\
\hline 25 & 24 & 2 & 12 \\
\hline 30 & 24 & 2 & 12 \\
\hline
\end{tabular}

$\mathrm{CPE}=$ cytopathic effect

Table (3) Experimental infection of 21 days old chicks with EDS-76 virus propagated on chicken liver cells (attenuated)

\begin{tabular}{|c|c|c|c|c|c|}
\hline $\begin{array}{c}\text { No. of } \\
\text { passages }\end{array}$ & $\begin{array}{c}\text { No. of } \\
\text { chicks } \\
\text { used }\end{array}$ & $\begin{array}{c}\text { No. of } \\
\text { dead } \\
\text { chicks }\end{array}$ & $\begin{array}{c}\text { mortality } \\
\text { percent }\end{array}$ & $\begin{array}{c}\text { No. of contact } \\
\text { control not } \\
\text { challenged }\end{array}$ & $\begin{array}{c}\text { No. of dead } \\
\text { contact } \\
\text { control } \\
\text { chicks }\end{array}$ \\
\hline $\mathbf{1}$ & 10 & 10 & 100 & 3 & 3 \\
\hline $\mathbf{5}$ & 10 & 10 & 100 & 3 & 3 \\
\hline 10 & 10 & 2 & 20 & 3 & 3 \\
\hline 15 & 10 & 4 & 40 & 3 & 0 \\
\hline 20 & 10 & 2 & 20 & 3 & 0 \\
\hline 22 & 10 & 2 & 20 & 3 & 0 \\
\hline 23 & 10 & 4 & 40 & 3 & 0 \\
\hline 24 & 10 & 0 & 0 & 3 & 0 \\
\hline 25 & 10 & 0 & 0 & 3 & 0 \\
\hline 30 & 10 & 0 & 0 & 3 & 0 \\
\hline
\end{tabular}


Table (4) Protection efficiency of chicken inoculated with different

EDS-76 virus passages on chicken liver cells after challenging test

\begin{tabular}{|c|c|c|c|c|c|c|c|}
\hline $\begin{array}{c}\text { No. of } \\
\text { passages }\end{array}$ & $\begin{array}{l}\text { No. of } \\
\text { challenged } \\
\text { chicks }\end{array}$ & $\begin{array}{l}\text { No. of } \\
\text { dead } \\
\text { chicks }\end{array}$ & $\begin{array}{c}\text { Morbidity } \\
\%\end{array}$ & $\begin{array}{c}\text { Mortality } \\
\%\end{array}$ & $\begin{array}{c}\text { PM } \\
\text { lesions }\end{array}$ & $\begin{array}{l}\text { No. of } \\
\text { challenged } \\
\text { control } \\
\text { chickens }\end{array}$ & $\begin{array}{l}\text { No. of } \\
\text { dead } \\
\text { control } \\
\text { chicks } \\
\text { nfter } \\
\text { challenge }\end{array}$ \\
\hline 10 & 8 & 4 & 50 & 50 & $\begin{array}{l}\text { typical } \\
\text { EDS } \\
\text { lesion }\end{array}$ & 3 & 3 \\
\hline 15 & 6 & 2 & 30 & 30 & $\begin{array}{l}\text { typical } \\
\text { EDS } \\
\text { lesion }\end{array}$ & 3 & 3 \\
\hline 20 & 8 & 4 & 40 & 40 & $\begin{array}{l}\text { typical } \\
\text { EDS } \\
\text { lesion }\end{array}$ & 3 & 3 \\
\hline 22 & 8 & 2 & 25 & 25 & $\begin{array}{l}\text { lypical } \\
\text { EDS } \\
\text { lesian }\end{array}$ & 3 & 3 \\
\hline 23 & 6 & 0 & 0 & 0 & - & 3 & 3 \\
\hline 24 & 10 & 1 & 10 & 10 & $\begin{array}{l}\text { lypical } \\
\text { EDS } \\
\text { lesion }\end{array}$ & 3 & 3 \\
\hline 25 & 10 & 0 & 0 & 0 & & & \\
\hline 27 & 10 & 0 & 0 & 0 & - & 3 & 3 \\
\hline 29 & 10 & 0 & 0 & 0 & & & \\
\hline 30 & 10 & 0 & 0 & 0 & - & 3 & 3 \\
\hline
\end{tabular}

Table (5) Sterility of the prepared EDS vaccines

\begin{tabular}{|c|c|c|c|}
\hline \multirow[b]{2}{*}{ Media } & \multirow{2}{*}{$\begin{array}{c}\text { Living } \\
\text { attenuated } \\
\text { EDS } \\
\text { CL cells } \\
\text { propagated } \\
\text { vaccine }\end{array}$} & \multicolumn{2}{|c|}{$\begin{array}{c}\text { inactivated EDS oil } \\
\text { emulsion vaccine }\end{array}$} \\
\hline & & $\begin{array}{l}\text { CL cells } \\
\text { propagated } \\
\text { vaccine }\end{array}$ & $\begin{array}{c}\text { embryonated } \\
\text { duck eggs } \\
\text { vaccine }\end{array}$ \\
\hline Nutrient agar media & $\mathrm{NC}$ & $\mathrm{NC}$ & NC \\
\hline Thioglycollate broth & NT & NT & NT \\
\hline Sabauraud's glucose agar & $\mathrm{NC}$ & $\mathrm{NC}$ & $\mathrm{NC}$ \\
\hline Grey media & $\mathrm{NC}$ & $\overline{\mathrm{NC}}$ & $\mathrm{NC}$ \\
\hline
\end{tabular}

$N C=$ No colonies appeared on used medium .

$\mathrm{NT}=$ No turbidity appeared on used broth. 
Table (6) Results of cell mediated immune response of chickens post vaccination with prepared vaccines using lymphocyte blastogenesis

\begin{tabular}{|c|c|c|c|c|c|}
\hline $\begin{array}{c}\text { Groups } \\
\text { No. }\end{array}$ & \multicolumn{2}{c|}{ Type of vaccines used } & \multicolumn{3}{c|}{ weeks post vaccination } \\
\hline $\mathbf{1}$ & $\begin{array}{c}\text { live attenuated EDS-76 propagated on } \\
\text { CL cells }\end{array}$ & 0.231 & 0.694 & 0.375 & 0.301 \\
\hline $\mathbf{2}$ & $\begin{array}{c}\text { inactivated oil emulsion EDS-76 } \\
\text { propagated on CL cells }\end{array}$ & 0.252 & 0.755 & 0.357 & 0.298 \\
\hline 3 & $\begin{array}{c}\text { inactivated oil emulsion EDS-76 } \\
\text { propagated on duck eggs }\end{array}$ & 0.116 & 0.175 & 0.122 & 0.090 \\
\hline $\mathbf{4}$ & control non vaccinated & 0.037 & 0.034 & 0.035 & 0.035 \\
\hline
\end{tabular}

Table (7) $\log _{2}$ mean neutralizing antibody titers of sera from vaccinated chickens with different prepared vaccines

\begin{tabular}{|c|c|c|c|c|c|c|c|c|c|c|c|c|c|}
\hline $\begin{array}{c}\text { Group } \\
\text { No. }\end{array}$ & \multirow{2}{*}{ Type of vaccines used } & \multicolumn{10}{|c|}{ weeks post vaccination } \\
\hline 1 & $\begin{array}{c}\text { live attenuated EDS-76 } \\
\text { on CL cells }\end{array}$ & 11 & 10 & 10 & 12 & 11 & 11 & 12 & 12 & 11 & 12 & 12 & 12 \\
\hline 2 & $\begin{array}{c}\text { Inactivated oil } \\
\text { emulsion EDS-76 on } \\
\text { CL cells }\end{array}$ & 11 & 5 & 10 & 12 & 12 & 12 & 12 & 10 & 12 & 12 & 12 & 11 \\
\hline 3 & $\begin{array}{c}\text { Inactivated oil } \\
\text { emulsion EDS-76 on } \\
\text { duck eggs }\end{array}$ & 4 & 6 & 5 & 7 & 8 & 11 & 7 & 11 & 12 & 12 & 12 & 12 \\
\hline 4 & Control non vaccinated & 0 & 0 & 0 & 0 & 0 & 0 & 0 & 0 & 0 & 0 & 0 & 0 \\
\hline
\end{tabular}

Table (8) Mean HI antibody titers $\left(\log _{2}\right)$ of sera from chickens vaccinated with different prepared EDS-76 vaccines

\begin{tabular}{|c|c|c|c|c|c|c|c|c|c|c|c|c|c|}
\hline \multirow{2}{*}{$\begin{array}{c}\text { Groups } \\
\text { No. }\end{array}$} & Type of vaccines used & \multicolumn{10}{c|}{ wecks post vaccination } \\
\hline 1 & $\begin{array}{c}\text { live attenuated EDS-76 } \\
\text { on CL cells }\end{array}$ & 0 & 4 & 6 & 6 & 9 & 8 & 10 & 7 & 10 & 10 & 7 & 7 \\
\hline 2 & $\begin{array}{c}\text { Inactivated oil } \\
\text { emulsion EDS-76 on } \\
\text { CL cells }\end{array}$ & 7 & 7 & 6 & 10 & 9 & 7 & 6 & 6 & 7 & 5 & 6 & 6 \\
\hline 3 & $\begin{array}{c}\text { Inactivaled oil } \\
\text { emulsion EDS-76 on } \\
\text { duck eggs }\end{array}$ & 9 & 10 & 9 & 9 & 8 & 8 & 8 & 7 & 7 & 7 & 7 & 7 \\
\hline 4 & Control non vaccinated & 0 & 0 & 0 & 0 & 0 & 0 & 0 & 0 & 0 & 0 & 0 & 0 \\
\hline
\end{tabular}


Table (9) Rate of protection of prepared EDS-76 vaccines

\begin{tabular}{|c|c|c|c|c|c|c|c|c|c|c|}
\hline \multirow[b]{2}{*}{$\begin{array}{c}\text { Group } \\
\text { No. }\end{array}$} & \multirow[b]{2}{*}{$\begin{array}{l}\text { Type of } \\
\text { vaccines } \\
\text { used }\end{array}$} & \multicolumn{3}{|c|}{$1^{\mathrm{st}}$ month } & \multicolumn{3}{|c|}{$2^{\text {ndd }}$ month } & \multicolumn{3}{|c|}{$3^{r d}$ month } \\
\hline & & 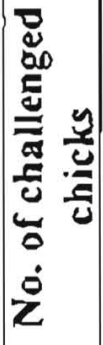 & $\frac{3}{\frac{3}{2}}$ & 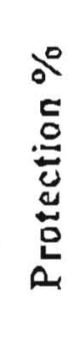 & 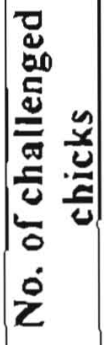 & $\frac{20}{2}$ & 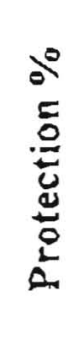 & 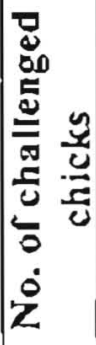 & 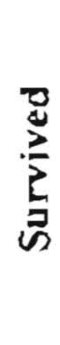 & 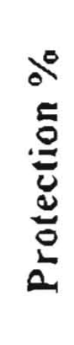 \\
\hline 1 & $\begin{array}{c}\text { live } \\
\text { attenuated } \\
\text { EDS-76 on } \\
\text { CL cells }\end{array}$ & 5 & 5 & 100 & 5 & 5 & 100 & 5 & 5 & 100 \\
\hline 2 & $\begin{array}{l}\text { Inactivated } \\
\text { oil emulsion } \\
\text { EDS-76 on } \\
\text { CL cells }\end{array}$ & 5 & 5 & 100 & 5 & 5 & 100 & 5 & 5 & 100 \\
\hline 3 & $\begin{array}{l}\text { Inactivated } \\
\text { oil emulsion } \\
\text { EDS-76 on } \\
\text { duck eggs }\end{array}$ & 5 & 5 & 100 & 5 & 5 & 100 & 5 & 5 & 100 \\
\hline 4 & $\begin{array}{l}\text { Control non } \\
\text { vaccinated }\end{array}$ & 5 & 0 & 0 & 5 & 0 & 0 & 5 & 0 & 0 \\
\hline
\end{tabular}

Table (10) Keeping quality of prepared EDS-76 vaccines

\begin{tabular}{|c|c|c|c|c|c|c|c|c|c|c|}
\hline \multirow{3}{*}{$\begin{array}{l}\text { Group } \\
\text { No. }\end{array}$} & \multirow{3}{*}{$\begin{array}{c}\text { Type of } \\
\text { vaccines used }\end{array}$} & \multirow{3}{*}{$\begin{array}{l}\text { Keeping } \\
\text { temperature }\end{array}$} & \multicolumn{8}{|c|}{ Duration of potency (montlis) } \\
\hline & & & \multicolumn{2}{|c|}{$I^{3 t}$} & \multicolumn{2}{|c|}{$2^{\text {nd }}$} & \multicolumn{2}{|c|}{$3^{\text {rd }}$} & \multicolumn{2}{|c|}{$4^{\text {th }}$} \\
\hline & & & $S$ & $\%$ & $S$ & $\%$ & 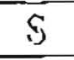 & $\%$ & $\mathrm{~S}$ & $\%$ \\
\hline 1 & $\begin{array}{l}\text { live attenuated } \\
\text { EDS- } 76 \text { on } \mathrm{CL} \\
\text { cells }\end{array}$ & $-20^{\circ} \mathrm{C}$ & $S / S$ & 100 & $5 / 5$ & 100 & $5 / 5$ & 100 & $5 / 5$ & 100 \\
\hline 2 & $\begin{array}{l}\text { Inaclivated oil } \\
\text { emulsion EDS- } \\
76 \text { on CL cells }\end{array}$ & $+4^{\circ} \mathrm{C}$ & $5 / 5$ & 100 & $5 / 5$ & 100 & $5 / 5$ & 100 & $5 / 5$ & 100 \\
\hline 3 & $\begin{array}{c}\text { Inactivated oil } \\
\text { emulsion EDS- } \\
76 \text { on duck } \\
\text { eggs }\end{array}$ & $+4^{\circ} \mathrm{C}$ & $5 / 5$ & 100 & $5 / 5$ & 100 & $5 / 5$ & 100 & $5 / 5$ & 100 \\
\hline 4 & $\begin{array}{l}\text { Control non } \\
\text { vaccinated }\end{array}$ & & $0 / 3$ & 0 & $0 / 3$ & 0 & $0 / 3$ & 0 & $0 / 3$ & 0 \\
\hline
\end{tabular}

$\mathrm{S}=$ survived chickens .

$\%=$ protection $\%$. 


\section{REFERENCES}

Adu, F. D.; Oyejide, A. and Tomorh, O. (1989): "Inactlvated oll cmulsion vacclines from sclected clones of Newcastle disease virus". Vet. Quarterly. 11 (3): 190-192.

Abmed, M. H. H. (1995) : "Viruses associated with drop in egg production". Ply.D. Thesis. Fac. Vet. Med. Cairo Unjuersity.

Anon, M. (1971) : "Methods for examination of poultry biologic and for identlfying and quantifying avlan pathogens", National Academy of Sclence, Washington D.C.. USA.

Bragg, R. R.; Allwright, D. M. and Coetzee, L. (1991) : "Isolatlon and Identification of adenovlrus 127, the causative agent of cgg drop syndrome (EDS). from commercial laying hens in South Afrlca". Onderstepoort J. Vet. Res., 58 (4): 309-310.

Calnek, B. W.: Barnes, John, H.; Charles, W. B.: Larry. R. M. and Salf. Y. M. (1997) : "Egg drop syndrome. Diseases of poultry". 9th edilion. pp. 633-642.

Khalaf, S. E. (1981) : "Fleld and laboralory experiment on immunizing of hens against EDS-76". Jnaugural Dissertation. Tielarzliche Hochschule, Hannover (1981). pp. 89.

Hamouda, M. S. M. (1988) : "A study on adenovirus infection in ducks". Ph.D. Thesls. Fac. Vet. Med., Asslut Untversity.

Holmes, H. C.; Webb, K. J. and Box, P. G. (1989) : "Vaccine for control of EDS-76". Vet. Rec. 124 (12): 309-310.

Kaur, A; Oberol, M. S, and Amarjit Singh (1997) : "Neutralizing antbody and challenge response to live and inactivated avian adenovirus- 1 In brollers". Troplcal Animal Health and Production, 29 (3): 141-146.

Rumar, K. U.; Krishnaswamy, S. and Reddy, T. V. (1989) : "Studles on EDS-7G vaccincs Immunizaton with killed adjuvanted vaccines". Ind. Vet. J., 71: 325-328.

Lce, L. F. (1984) : "Proliferative response of chicken B and T lymphocytes to riltogens". Vet. Med. . 15: 44-52.

MeFerran, J. B.: Conaor. $T$. J. and Adalr, B. M. (1978) ; Studies on the antigenic relationshlp between an Isolate 127 from the EDS-76 and a fowl adenovirus". Avlan Pathol.. 7: 629.

Pedro, V. and Gerhor, H. P. (1880) : Titration of blologlcal suspension in isolation and identifjcation of avian pathogens". 2nd edition. pp. 124-128.

Parscblke. C. D. (1989) : "The use of embryonic chicken liver cell culture for the dlagnosls of virus infectlons in hens". Arch. Exp. Vet. Med.. 43 (3): 345-350. 


\section{Nancy Botros Rofail}

Phillps, J. M. (1973) : "Vacclnation against ND: asscssment of haemagglutinalion inhilbitum Illers obtained from fleld samples". Vel. Rec.. 43: 577-583.

Rhee, Y. O.: Kin, J, H. and Namgoong, S. (1987) : "Immunogenlclly of ND, EDS-76, 113D con1blned oll adjuvant vaccine". Research Reports of the Rural Development Administration (Livestock and Veterinary). 29 (1): 209-2 I2.

Reed. L. T. and Muench. $\boldsymbol{H}$. (1938): "A single method for estimating 50\% end point". Amer. J. Hung., 27: 493-497.

Rosslter, P. B.: Tessett, D. M. and Taylor, W. P. (1985) : "Microneutralizalion system Ior usc with different strains of peste des petit runilnants virus and rincierpest virus". "「irop. AnImal Hith. Prod.. 17 (2): 75-81.

Swain, P.; Kataria, J. M.; Verma, K. C. and $\operatorname{Sah}_{1}$ R. L. (1993) : "Experimental studies wilh an indigenous isolate of EDS-76 in chicken". Indian Journal of Animal Sciences. 63 (6): $591-595$.

Van Eck, J. H. H.: Davelaar, F.G.; Heuval-Plesman Van Den; Kouwenhoven, B. and Guldle. F. H. (1976): "Dropped egg prodluction, soft shclled and shell less eggs assoclated wills appearance of precipltins to adenovkrus in flocks of laying fowls". Avlan Pathol.. 5: 26)272.

Zsak, L.; Szekely, A and Kusary, T. (1982): "Expermental infection of young and laying geese with egg drop syndrome 1976 adenovirus strain B 8/78". Avlan Pathol.. 11: 55-56. 
الماتمص العربى

دراسات مقارنة على لقاح حى مستضهف ولقاح زيتى ميت ضد الفيرور

المسبب لمرض تدنى البيض فى الدواجن المحضر على خلايا الكبد من كتاكيت

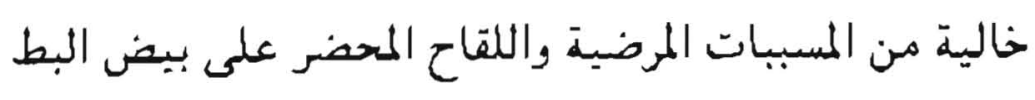

\author{
نانسى بطــرس روفائيـل

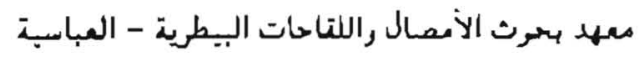

تم تحفير خلايا الزرع النسيجى (CL) من كتاكيت خالبة من المسببات المرضية راستخدمت كبديل لإنتاج لقاح حى مستضعف

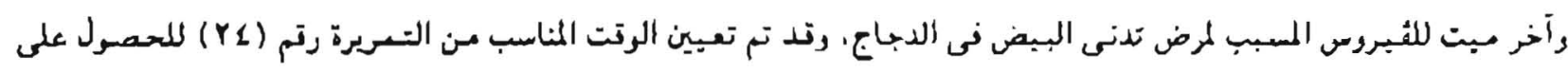

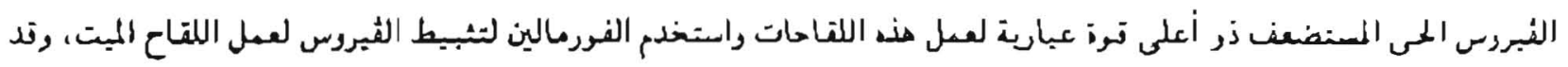
تم عمل دراسة مفارنة بين اللقاحات المضرة على خلابا الزرع النسبجى (CL) واللقاع الزيتى الميت المحضر محليا على بيض البط

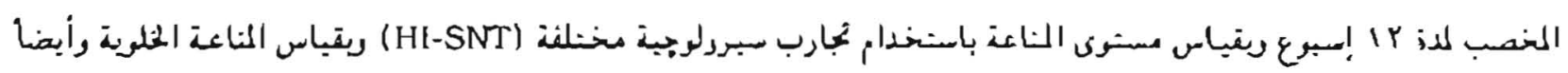

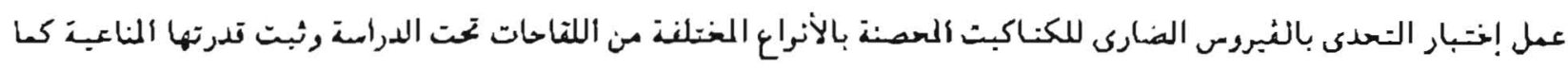

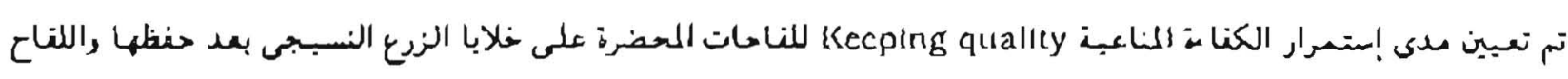

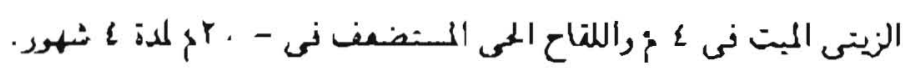

